\title{
Fiscal Consolidation and the New Flat Rate Individual Income Tax in Hungary
}

\author{
Mihály HŐGYE*
}

\section{New government initiatives on tax policy}

In the last two years the Hungarian people have witnessed several new measures in government's fiscal policy. To respond to global crisis that hit Hungary hard, the Bajnai government enacted a series of economic reforms and spending cuts in 2009. The measures included reforms to the pension and entitlement systems, as well as tax changes to shift the tax burden from labor to wealth and consumption. In addition to cuts in taxes for businesses and employees, tax changes included raising the value added tax (VAT), and a proposal for the introduction of a property tax.

The very harsh economic conditions led to social and political turmoil. The elections of 2010 brought a landslide victory with two-third majority to the centre-right Fidesz Party that had campaigned on a promise of less austerity. The new government launched economic programs designed to promote growth by reducing administrative burdens on businesses and lowering the tax burdens on small businesses. The plan also includes strict control of budgetary expenditures, and a "crises-tax" on different sectors which would remain in effect for minimum 2 years. One of the most popular plans is the launch of a "flat-rate" individual tax replacing the existing progressive tax aiming to increase supply of labor and so tax base, to improve tax compliance and the reduce cost of taxation. The announcement of the plan has immediately criticized by the political parties in opposition and by many prominent economists. Although the idea is not new for the Hungarian politicians: in the last twenty years two parties, the Hungarian Democratic Forum and the Alliance of Free Democrats, had put it on their flags in time of campaigns.

Mihály Hőgye - Associate Professor, Head of Department of Public Policy and Management; Corvinus University of Budapest, Fővám tér 8, 1093 Budapest, Hungary; <mihaly.hogye@uni-corvinus.hu>. 
At first glance it seems to be that this new fiscal measure has just basically anti-consolidation effects on government budgetary position loosing significant revenues from income taxes. In short run, of course, the loss of revenue can be offset by temporary measures or finding new sources by some systematic changes in the revenue side. The 'crisis taxes' on some sectors are examples for the first group of measures. The 'nationalization' of private insurance funds is an example for systematic change. I do not deal with details of these measures.

In light of these measures questions related to the introduction of flatrate individual income tax system fundamental questions arise. Has it been a conscious and right decision by the government in fiscal troubles? Does this decision have enough economic theoretical and experimental support or is this just for rewarding voters and for keeping campaign promises? Or is it part of the government's long term strategy for shifting tax policy towards a "true" flat rate system? Are there other considerations that support the reform?

Answering these questions we should rely first on the official statement of the Ministry for National Economy. (The ex-Ministry of Finance is now part of the Ministry for National Economy in Hungary.) In the statement (Ministry for National Economy, 2010) one can realize some sort of rhetoric:

"We are witnessing the creation of the simplest tax system in the European Union and its acceptance will be yet another Hungarian specialty, a 'new Hungaricum'”.

"...we expect the once-glorious competitor who has been lagging far behind finally to break through to a leading position in Europe. With its soon-to-be introduced tax system, Hungary aims to become the most competitive country in Europe. The proportionate, transparent, family-friendly personal income tax system will serve this end."

Beyond rhetoric the statement argues with the expected positive impacts of the new system and sets priorities. These are:

- improving the competitiveness of the Hungarian tax system;

- creating family-friendly taxation with tax credits for each child, reducing the tax liabilities of families with children, this solution may help ease the country's demographic problems;

- creating proportionate and uncomplicated taxation. 
The statement also lists the major expectations from launching the new system:

- The complicated personal income taxation system is simplified, because every type of income is subject to the same tax rate.

- A lower tax rate encourages higher performance, people will have more disposable income, resulting in a higher level of both consumption and savings.

- Tax declaration, monitoring and tax administration will be less complicated and more transparent.

- The positive impact on economic competitiveness makes it attractive for domestic and foreign investors alike.

- In spite of an initial fall in tax revenues, the new system may eventually result in an increase in tax revenues for the central administration, as more and more people evading tax will declare their income and become legal taxpayers.

- Employees will have more disposable income and the costs of employment will fall.

- The effects of a reduced tax burden will become apparent from 2012, and calculations indicate that this will help create around 40000 new jobs annually.

As far as implementation of the new system concerns the statement has a long list of measures. Here I put some highlights:

- there is a uniform, flat-rate tax imposed on every type of income;

- the over taxation of employment and the disproportional tax burden have been overcome, the new system brings about a substantial change; everyone in work enjoys the advantages of these measures;

- the "super-gross" principle for defining tax base will gradually be abolished;

- individual personal income tax is reduced for all income, not only for salaries: the tax rate is 16 percent on all income. On the sale of real estate, dividends and interest, most cases the reduction is $9 \%$, a substantial change.

1 In the current regulation the definition of tax base equal to $127 \%$ of income. This tax base supplement will be cut to $13.5 \%$ (i.e. by half) in 2012 and from 2013 will no longer exist. 
- The tax credits system is being retained with some modifications, but a new family tax credit system for families with children is being applied.

In order to judge points of the statement it is worth looking for some lessons from theoretical approaches and international experiences of similar tax reforms.

\section{Some theoretical issues concerning progressive and flat rate tax systems}

"The hardest thing in the world to understand is the income tax." Albert Einstein (cited by Jackman, 1984)

Why tax systems are so complicated? The answer is found in the known and widely accepted tax principles (Högye, 1997). The principles of taxation can be defined as comprehensive and systematic views and ideas related to taxation. In modern economics principles of taxation can be summarized in the following scheme:

A tax system

- ought not to distort the optimal allocation of production factors in efficient markets;

- ought to be fair;

- ought to be a flexible automatic stabilization;

- ought to be clear and transparent, and definitive;

- ought to provide inexpensive collection.

These ideas put emphasis on economic effects of taxation simply because of its significant growth in the economy. However, the contents of these general principles have changed considerably. In the 18th century the main question was one of equity -- to dismantle privileges. Today the main question may be the level of progressivity or the ability to pay or satisfactory level of government revenue. Principles can be interpreted in different ways and their interpretation depends on how people treat contradictions such as tradeoffs between equity and efficiency.

From one view the principles of taxation can be divided into equity and efficiency issues. From another view these can be divided into two general groups. The first group is the positive principles of taxation, 
which concerns the effects of taxation. This is a 'technical' approach, such as how to minimize the cost of taxation. Hence the most important positive principles of taxation are tax shifting and the excess burden, or welfare cost of taxation. The second group of principles refers to tax policy issues, to the 'values'. This is a normative approach to describe a fair and good tax policy and system.

A basic issue in public finance is to distribute among people the burden of financing the cost of public goods and services. There is no way of distributing these costs that will satisfy all citizens. However, there are principles for doing this. The most basic distinction in the equity dimension of public finance is the one between ability to pay and benefits received as the basis for setting and judging taxes. The ability-to-pay principle is concerned with raising revenue and it focuses on the distributive nature of taxation. The benefit principle is concerned with expenditures and this focuses on a fair way to pay for the benefits government provides. An alternative view of equity, related to the benefit principle, is the principle of marginal cost pricing.

The ability-to-pay principle states that taxes should be distributed according to the capacity of taxpayers to pay them. This sounds reasonable and fair, but questions arise in any interpretation, for example, how to measure ability-to-pay, how to determine a fair set of tax rates based on differing abilities to pay, how to compare the economic positions of various individuals.

This principle of taxation has two specific equity principles. The first is one of the most widely accepted principles or norms for distributing taxes among individuals. It maintains that individuals in similar situations should be treated similarly, or similarly equals should be treated equally. This is the principle of horizontal equity. The origin and general acceptance of this principle in democratic societies are not difficult to explain. Horizontal equity seems to be the easiest principle of taxation to justify. The problem arises at the time of specifying and implementing equity. The ability-to-pay has normally been measured by incomes and wealth. The principle suggests that tax rates should vary directly with income and wealth. If income is used, one should tax individuals with the same income by the same amount. However, the problem is that people obtain income individually and spend it in households. Should a family be treated as a group of individuals with income for each equal to the total family income divided by the number of family members? How should 
tax policy treat married couples or families with different numbers of dependents? Is it a private matter if somebody cares for their children alone or is it also a public affair? If it is the latter how it should be awarded? Is it achieved through taxation or through social benefits? What about people who have very high medical expenses? How do these different questions fit into other budgetary or economic principles? In practice, the attempt to maintain horizontal equity can be extremely complex, since it is hard to reach agreement on what constitutes equality.

A corollary of this equity principle states that unequal should be treated unequally. This is widely referred to as the principle of vertical equity. However, distributing the total tax bill among the different classes and groups of taxpayers presents many difficulties. To what extent should discrimination in tax rates among separate classes and groups be accepted? The concepts of progressive, proportional, and regressive taxes were developed to help address this issue. Namely, attempts have been made to define ability to pay in order to justify progressive taxation. It has been argued that the ability-to-pay principle has not been met unless highincome groups pay proportionately more than the low-income groups.

The extension of the ability-to-pay principle to the concept of progressive taxation is not supported on scientific or analytical grounds. The justification or explanation of progressive taxation must rest on different grounds as the ability-to-pay principle leads to no specific configuration of taxes apart from the single proposition that higherincome receivers should pay higher taxes. Even if the above problem could be solved a practical issue still remains: the concepts should be interpreted for the whole tax system not just for the separate tax forms. In other words, not every tax should necessarily be progressive. One solution to the dilemma is through agreement upon the legal or constitutional framework in which political decisions about distributional matters are to be reached.

An additional consideration that cannot be overlooked when dealing with the issue of progressive taxation relates to the effects of such taxation upon the level of income. In responding to an income tax the taxpayer may choose to work, save, or invest less. As will be explained, this imposes an efficiency burden on him. Moreover, if progressive taxation is viewed as an instrument for redistributing income, progressive rates must not be carried too far. Raising rates beyond the point at which they become so burdensome that they eliminate the incentive to increase 
work effort and earnings will lead to declining revenue, thus leaving less for redistribution to low-income groups.

An alternative principle for distributing the tax load among separate individuals and groups states that tax obligations should be based on the benefits received from the enjoyment of public services. This is called the benefit principle, and it has the advantage of linking, the discussion of tax equity with the expenditure side of the public budget. This link is basically absent in the context of the ability-to-pay principle, which considers only the tax side. Taxes are viewed as a price paid for these services, more or less similar to the price paid for the purchase of private goods.

A good tax system should not only be equitable but it should also be efficient. As with all economic activity, public or private, waste should be avoided. This has two specific meanings for tax policy: taxes should not impose an "excess burden"; and the cost of tax administration and taxpayer compliance should not be excessive, relative to the revenue obtained. Analyses of taxation aimed at providing appropriate advice for tax policy can investigate tax matters from two aspects: how to improve equity at a given level of efficiency, or how to minimize welfare cost at a given level of equity.

However, taxation is only a part of public finances. In modern welfare societies the political forces formulate their tax policy and tax system along the line of their objectives in social policy. It relates first of all to formulate individual income tax system. Most of the modern societies apply a sort of progressive individual income tax system planting principles of horizontal and vertical equity to the practice in order to accomplish social policy objectives through income redistribution.

Criticism on progressive income taxation holds two - in many cases quite opposite - views to accomplish social policy objectives. The first stream argues that any direct links between social policy and taxation would lead to distortions in economic relations and hence any attempt to build social policy objectives into the taxation system would lead an inefficient economic system. This approach is represented by the supporters of the "true" flat-rate tax system. On the other hand, the experience of welfare states shows that the tax policy must significantly include a socially accepted redistribution of wealth through primarily taxation. The proponents of the so-called "negative income tax" propose a 
full integration of the social policy and individual income taxation by which any other form of social (welfare) benefits would not be necessary and government would get rid of significant costs of running different, in many cases inefficient benefit programs (except social security).

Now I pay attention to the first stream, the flat-rate system.

"The flat-tax idea is big enough and simple enough to be worth taking seriously." (Economist, 2005)

The phrase flat rate tax is used to describe a tax system in which corporate and private income tax payers all pay income tax according to the same rate, and not at different and progressive rates. The marginal tax rate is a constant at all levels of income. (Kesner-Škreb, 2005, pp. 205208)

The most discussed flat-tax proposal has been developed by Robert E. Hall and Alvin Rabushka (1995) of the Hoover Institution. It taxes all types of income once and at one rate. It contains no tax credits, deductions, or exemptions except for the personal, spousal, and child exemptions. Flat-tax reform significantly simplifies the determination of income. It is an integrated approach to taxation wherein both business income and personal income are taxed once and only once.

The proposal is for a very precisely defined and coherent tax structure: a combination of a cash-flow tax on business income and a tax on workers' income, both levied at the same, single rate (with a personal allowance available against the wage tax). The base of the business tax would be the difference between receipts from sales, including exports, and payments for purchases of inputs and capital goods, both domestically produced and imported, and to employees. The tax on workers' income would be assessed on any kind of compensation to labor (including the value of fringe benefits) and on pension benefits. In effect, the HR flat tax is a consumption-type, origin-based value-added tax (VAT) collected by the subtraction method, supplemented by a (nonrefundable) tax credit against labor income. (Keen et al., 2006)

Proponents of Hall-Rabushka model are very enthusiastic about the advantages of the flat rate tax system. They argue that this type of integrated approach to taxation achieves horizontal equity, the principle that people with similar incomes should bear similar tax burdens. The 
personal exemption ensures vertical equity is achieved; that is, as people earn more, they pay more. Thus, it achieves both measures of equity, the second criteria of tax policy. Another benefit of Hall-Rabushka is that it effectively moves the income-tax system away from taxation of income towards taxation of consumption. A consumption tax is levied on any income that is consumed, i.e., spent rather than saved. The exclusion of savings (investments) effectively creates a tax system based on taxing consumption rather than income and, thus, achieves the third of the tax criteria, efficiency. The net economic effect is to improve incentives for work, increase entrepreneurial activity, and capital formation (Basham et al., 2001).

Others are a little bit more cautious concerning potential tax reforms on the basis of flat-rate model. They argue that without the personal exemptions, the flat tax would be equivalent to a VAT, but with taxes on wages remitted by households rather than business. That is, the flat tax would be a consumption tax, even though it would look like a wage tax to households and a variant of a VAT to most businesses. The family exemptions make the flat tax progressive for low-income households. But at the high end of the income distribution, the tax is regressive, just like sales taxes and VATs. In principle, replacing the income tax with a consumption tax, such as the flat tax, offers the possibility of improving the efficiency, equity, and simplicity of the tax system. But these gains are uncertain and depend critically on the details of the reform (Gale, 1999).

\section{Some lessons from tax reforms in Central and Eastern Europe}

The Hall-Rabushka model has motive wide academic and political discussions. However, before the mid nineties only few countries (the frequently cited Hong Kong and the Channel Islands) implemented a flat tax, since 1994 there are nearly thirty countries worldwide with flat tax systems, about half of which are situated in Central-Eastern Europe. Keen et al. stresses that discussion of these quite radical reforms has been marked, however, more by assertion and rhetoric than by analysis and evidence. The flat taxes that have been adopted differ fundamentally, and that empirical evidence on their effects is very limited. (Keen et al. 2006) 
It worth noting that there are major differences between a potential comprehensive tax reform that results from a flat-tax model of taxation such as Hall-Rabushka and the incremental (partial) reform that results from replacing multiple rates of taxation with a single rate. The replacement of multiple rates of taxation with a single rate, although an important tax reform, does not change the tax system in the fundamental way that a flat tax does. This is recognized by an OECD study on fiscal policy and economic growth (Saavedra, 2007) that distinguishes four variations of the existing flat rate income tax systems:

- flat rate taxation without a basic allowance;

- flat rate taxation with a basic allowance;

- flat rate taxation with a refundable tax credit;

- flat rate taxation extended to business incomes.

The flat-tax revolution has been sweeping through Central and Eastern Europe. Estonia was first who adopted the flat tax then Georgia, Latvia, Lithuania, Russia, Romania, Slovakia, Ukraine, Serbia, Albania, Czech Republic, Montenegro, Poland, Republic of Macedonia, and Hungary have introduced the flat personal income tax rate.

There are relatively few analysis concerning experiences with flat rate and there are still debates among countries about the relations between expectations and results of the introduction of the new system. Some highlights concerning the above:

Although in the first wave of low-rate flat tax reforms the Baltic nations experienced high economic growth, there are no sign of Laffertype behavioral responses generating revenue increases from the tax cut elements of these reforms. The second wave of low-rate flat tax reforms has been associated with a reduction in revenue from the personal income tax. (The exception is Russia where the strong revenue performance after the reform might be due macroeconomic factors than to the flat tax itself.) (Keen et al., 2006)

In rhetoric a potential gain has been expected with the flat tax by the simplification of tax filing, with proponents dreaming of a tax return fitting on a postcard or a beer coaster which may lower the costs of tax compliance and administration. There is evidence that compliance improved after the Russian reform but there is no firm evidence that it was due to the parametric tax reform rather than to changes in 
enforcement (tax amnesty) occurring around the same time (Keen et al., 2006). Such reforms could be useful in countries experiencing large tax evasion but the governments should not expect a large productivity response. It could explain why flat tax reforms are especially popular among former socialist countries that are plagued by large shadow economic activities (Sabirianova et al., 2009).

In most of flat-rate countries the tax rate is not uniform, that means different rates are applied to business and to individuals, and even the VAT rates are different. Furthermore, systems of social security contributions that operate like income taxes put additional burden on individuals. In many cases the introduction of flat rate income tax proved to be advantageous not because of the single rate but rather because of opportunity is opened for simplification of tax administration and widening the tax base (Kiss et al., 2008). While flatness itself is certainly a simplification, eliminating some potential forms of tax arbitrage, the rate structure itself is commonly not the primary source of complexity in taxation. This comes more from exemptions and special treatment of various kinds (Keen et al., 2006).

The impact of the flat tax on work incentives is not clear cut in principle, and there is no evidence that it has been strong in practice (Keen et al., 2006). My hypothesis is that incentives might have stronger effect only in short period. Right after the lowering of the marginal rate the new opportunities for earning more net income are quickly opening. However, some years later the opportunities are narrowing when people get accustomed to the changes.

The distributional effects of movement towards a flat tax are potentially complex: second wave reforms that involve an increase in the basic tax-free amount are beneficial to both the lowest and the highest earners, and compliance effects may in themselves plausibly lead to an increase in effective progressivity.

While the question has received little attention in the debate, and appears not to have been studied empirically, movement to a flat tax may plausibly strengthen the automatic stabilizers, not weaken them (Keen et al., 2006).

The rate-cutting aspect of the second wave reforms has enabled some countries to construct a political package that has included significant 
base-broadening through the elimination of various exemptions and preferences. A flat tax would not eliminate the need for spending control; it would not deal with the impending financial distress of Social Security and Medicare; it would not even settle the arguments about the so-called consumption tax (since in principle a flat tax could take as its base either all income, or income net of savings, in which case it would act as a consumption tax). There are things it cannot do and questions it does not answer. But the gains from a radical simplification of the tax system would be very great. The possibility should not be excluded at the outset (Economist, 2005).

An interesting analysis deals with the issue of contemporary flat-tax reforms in Eastern Europe and aims to account for the different approaches that various European countries adopted towards the idea of a flat-tax. Empirically, the work is based on detailed studies of Slovakia, the Czech Republic and Germany. The analysis considers three factors being decisive for the flat-tax feasibility: party system institutionalization, coalition/opposition cohesiveness, labor union institutionalization. Although all identified factors seem to be at play with regard to flat-tax feasibility, it is either the strength or the weakness of labor unions' institutionalization and welfare identity that underlie the political decision-making in the East and the West and as a result determine the flat-tax (un-feasibility). The absence of welfare identity in the East allows for higher coalition cohesion in favor and weaker opposition against the flat tax adoption in contrast to the West (Antalova, 2010).

\section{Arguments in Hungary for and against the flat rate individual income tax introduced in 2011}

In light of the international lessons and the expectations in the official government statement in Hungary, now I pay attention some additional arguments which support or oppose the reform of personal income tax system.

After the system change in Hungary people have to give up the illusion of an egalitarian system that was supposed to provide a comprehensive social halo over the society. The transition process has proved to be very painful concerning social safety and the classical principles of taxation. It means, first of all, that the country has established a "world-conform" income tax system but with a purer 
structure with regards to social considerations. It has been a relatively simple task since before there was no comprehensive individual income tax system at all. On the other hand, budgetary policies have required a tax rates with a relatively high progressivity and that has led to controversial solution in running a social policy parallel with a fiscal policy.

In Hungary many of the social policy issues were separated from the central fiscal policy, namely the secession of health and pension systems' management from the state budget shows that the links between social policy and taxation were partly buried at least for a time.

Another signal for separating the two policies was a "liberal" economic policy which curtailed social benefits not only in the separate social benefit systems but in taxation as well. An example of this policy is the 1995 "Bokros-package" which was an "across-the-board" cut in budget expenditures, social benefits among them. Beside these measures taxation policy relied on its very simple basic objective: to collect the required amount of taxes and tax-like revenues in a structure of taxes where other than fiscal considerations can hardly be recognized.

A flat rate personal income tax harmonized with the national insurance system could serve as the basis of a budgetary system built on an easy-to plan revenue base. Also, it needs to be taken into account that the successful operation of a tax system largely depends on taxpayers' willingness to pay taxes. A clearly structured, transparent tax system that can be understood by everyone may positively influence taxpayers' such willingness (Vörös et al., 2010).

Since Hungary has had to face the tax competition within the Central and Eastern European region for a long time now, lowering tax rates provides advantages in that competition.

As far as equity questions concern first, prior to 2011 the Hungarian personal income tax system imposed a linear tax on incomes of significant sizes (i.e. on separately taxed incomes such as incomes relating to movable and immovable assets, capital incomes, etc.). Secondly, thanks to the two tax brackets applied and the tax bracket thresholds, it was in fact linear taxation applied in a significant proportion of the cases. If there is no significant difference between tax rates, a small number of tax brackets are set, and these brackets are set rather narrow - 
like in Hungary - progressive taxation makes little sense. From this point of view, it is indeed right to dismiss the idea of flat rate taxation in the name of social justice (Vörös et al., 2010).

Taxes are often used as instruments of policy. In my view a flat tax system such policy mechanisms may be curtailed. In addition to social policy, flat taxes can remove tools for adjusting economic policy as well.

As I mentioned earlier the "attack" on progressive income taxation holds two - in many cases quite opposite - views to accomplish social policy objectives. The first stream argues that any direct links between social policy and taxation would lead to distortions in economic relations and hence any attempt to build social policy objectives into the taxation system would lead an inefficient economic system. This approach is represented by the supporters of the "true" flat-rate tax system. The proponents of the so-called "negative income tax" propose a full integration of the social policy and individual income taxation. Between the two extremes the experience of welfare states shows that the tax policy should include a socially accepted redistribution of wealth through also taxation. In many developed countries a wide range of tax expenditure is still applied in a more or less progressive personal income tax system.

The main problem of implementing a flat rate tax could be to convince a majority of the population that redistribution in favor of the highest income deciles is acceptable. These distributional effects at the expense of the middle class might explain why flat rate taxes have not been successful in the political process in Western Europe. Furthermore, it is uncertain whether a tax system that abolishes a large number of exemptions and tax reliefs is politically sustainable. The temptation for politicians to serve special interest groups with special deductions will not easily disappear. Moreover, from a political economy perspective, a broad tax base allows the government to increase revenue with small increases in tax rates. Therefore, narrow tax bases might be disadvantageous for a given amount of tax revenue; nevertheless, they might protect the taxpayers from excess taxation by the government (Fuest et al., 2007).

Here is one of the main points of my paper. The flat rate reduces the flexibility of government to use tax rates as one of the "strong" weapons in budgetary policy when it becomes unavoidable. I mean that politically is not profitable to raise the "uniform" rate in order to generate revenue in 
case of budget deficit. Hence the government should apply other measures to raise revenues or decrease expenditures. Among these measures one can find levying temporary "crisis" taxes, reducing tax expenditure, cutting wages or eliminating jobs in the public sector, freezing public operational expenses, not increasing the real or even nominal value of pensions and other social benefits.

One of the obvious measures of applying taxation for achieving social policy purposes is the system of tax expenditures. The idea of tax expenditures has been recognized in most developed countries and they have extensively been used for providing benefits through taxation for those who are eligible from social point of view. Tax expenditures are special provisions which result in reductions in tax revenues. Typically they take the form of exclusions, deductions, credits and deferrals. It is important to note that differences of opinion exist both among analysts and tax practitioners as to what constitutes tax expenditure. There are various ways to deal with these differences, ranging from reporting on only a restricted set that all would agree are tax expenditures to re porting on a very broad set which includes every item that could potentially fall into this category.

In welfare states the system works. The vast majority of taxpayers comply fully with the law. However, as in any tax system, there are instances where taxes are not paid or not paid on time. Tax law is complex and every effort must be made to simplify the system for those who may not have access to professional advice. There may be those who have experienced circumstances beyond their control preventing them from paying on time. Others may have no financial means to pay due to a pending bankruptcy. Also, there are those who avoid or evade taxes.

However, the system proves that in case of honest tax compliance the benefits are provided. In other words, the complexity of the personal income taxation rather serves the general social policy than the tax avoidance. The above raises a crucial question that to what extent taxation could or should embrace social policy objective? A demanding need from economic efficiency view is to reduce the number and amount of preferences in taxation and reallocate resources to more effective forms of government aids. 
Does the Hungarian government have options in exercising social policy through income taxation? What does the separation of social policy and taxation really mean?

As state ownership diminishing through privatization and as new private activities emerge, the tax system needed to become more predictable and less discretionary. Expansion of new small firms in the private sectors cannot provide immediate extra profit and thus more tax revenue. Moreover, this sector has a particularly strong tendency to understate revenues and to find tax loopholes.

The practice of levying and collecting tax has changed greatly with the introduction of market reforms. A huge increase can be seen in the number of taxpayers. Whole new categories of persons became subject to taxation, requiring them to keep records, submit returns and pay tax. The extent to which taxpayers are informed and educated about fiscal discipline and tax rules has become a crucial element in the success or failure of the tax compliance system.

Here is another main points of my paper: in a system where tax expenditures are widely used tax compliance may systematically improved if burdens and benefits are linked, hence it is very beneficial for taxpayers if they submit their tax returns stating their real social position. Improving tax compliance requires a relatively strong link between reasonable voluntary compliance by individual taxpayers and chances for being benefited through tax preferences. This is the main reason why the government should somehow build social policy targets into income taxation. In other words, of course one can separate and evaluate social policy objectives and tax policy objectives, but as a matter of implementation it is desirable to operate them partly in one mechanism.

\section{Conclusions}

In Hungary one of the most popular plans has been the launch of a "flatrate" individual income tax replacing the existing progressive tax aiming to increase supply of labor and so tax base, to improve tax compliance and the reduce cost of taxation. At first glance it seems to be that this new fiscal measure has just basically anti-consolidation effects on government budgetary position loosing significant revenues from income taxes. 
In light of lessons of international experiences it is more expressed that there are no sign of Laffer-type behavioral responses generating revenue increases from the tax cut elements of these reforms. The second wave of low-rate flat tax reforms in Central-Eastern Europe has - in most cases been associated with a reduction in revenue from the personal income tax. The impact of the flat tax on work incentives is not clear cut in principle, and there is no evidence that it has been strong in practice. Incentives might have stronger effect only in short period. Right after the lowering of the marginal rate the new opportunities for earning more net income are quickly opening. However, some years later the opportunities are narrowing when people get accustomed to the changes.

The flat rate reduces the flexibility of government to use tax rates as one of the "strong" weapons in budgetary policy when it becomes unavoidable. I mean that politically is not profitable to raise the "uniform" rate in order to generate revenue in case of budget deficit. Hence the government should apply other measures to raise revenues or decrease expenditures.

Criticism on progressive income taxation holds two - in many cases quite opposite - views to accomplish social policy objectives. The first stream argues that any direct links between social policy and taxation would lead to distortions in economic relations. This approach is represented by the supporters of the "true" flat-rate tax system. On the other hand, the proponents of the so-called "negative income tax" propose a full integration of the social policy and individual income taxation by which any other form of social (welfare) benefits would not be necessary (except social security). Between the two extremes the experience of welfare states shows that the tax policy should include a socially accepted redistribution of wealth through also taxation. In many developed countries a wide range of tax expenditure is still applied in a more or less progressive personal income tax system. In a system where tax expenditures are widely used tax compliance may systematically improved if burdens and benefits are linked, hence it is very beneficial for taxpayers if they submit their tax returns stating their real social position. Improving tax compliance requires a relatively strong link between reasonable voluntary compliance by individual taxpayers and chances for being benefited through tax preferences. 


\section{References}

[1] Antalova, L. (2010): Contemporary Flat-Tax Reforms in Eastern Europe. Causes of Diverse Approaches: A Comparison of Slovakia, Czech Republic and Germany. [on-line], Wien, Wirtschaftsuniversität, c2010, [cit. 10. 2. 2011], <http://epub.wu.ac.at/1626/1/document.pdf>.

[2] Basham, P. - Clemens, J. - Emes, J. - Walker, M. (2001): Flat Tax: Principles and Issues. [on-line], Vancouver, Fraser Institute, c2001, [cit. 10.2. 2011], <http://www.fraserinstitute.org/WorkArea/DownloadAsset.aspx?id= 2839>.

[3] Fuest, C. - Peichl, A. - Schaefer, T. (2007): Is a Flat Tax politically feasible in a grown-up Welfare State? [on-line], Köln, Finanzwissenschaftliches Forschungsinstitut an der Universität zu Köln, Discussion paper No. 07-6, c2007, [cit. 10. 2. 2011], <http://www.fifo-koeln.org/pdf/FiFo-CPE-DP_07-06.pdf>.

[4] Kiss, S. C. - Scharle, Á. - Szabó, B. - Szabó, P. A. (2008): Tax reforms in Europe. Reforms in Eastern Europe: The Flat Rate Tax System. Külgazdaság, 2008, vol. 52, no. 9-10, pp. 7-33.

[5] Economist (2005): Simpler taxes, the flat-tax revolution, Fine in theory, but it will never happen. Oh really? [on-line], Economist, $14^{\text {th }}$ April, 2005, [cit. 10. 2. 2011],

<http://www.economist.com/node/3861190>.

[6] Gale, W. G. (1999): Flat Tax. In: Cordes, J. - Ebel, R. D. Gravelle, J. G. (eds): The Encyclopedia of Taxation and Tax Policy. Washington, D.C, Urban Institute Press, 1999, pp. 155-158.

[7] Hall, R. - Rabushka, A. E. (1995): The Flat Tax. Stanford, Hoover Institution Press, 1995.

[8] Hőgye, M. (1997): Principles of Taxation. In: Nemec, J. - Wright, G. (eds.): Public Finance: Theory and Practice in the Central European Transition. Bratislava, Nispacee, 1997, pp. 139-169.

[9] Jackman, M. (1984): The MacMillan Book of Business and Economic Quotations. New York, MacMillan, 1984. 
[10] Keen, M. - Kim, Y. - Varsano, R. (2006): The "Flat Tax(es)": Principles and Evidence. [on-line], Washington, D. C., International Monetary Fund Working Papers 06/218, c2006, [cit. 10. 2. 2011], <http://www.imf.org/external/pubs/ft/wp/2006/wp06218.pdf>.

[11] Kesner-Škreb, M. (2005): A Flat Consumption Tax Concepts. Financial Theory and Practice, 2005. vol. 29, no. 2, pp. 205-208.

[12] Ministry for National Economy (2010): Hungary's Flat-rate Personal Income Tax. [on-line], Budapest, Ministry for National Economy Hungary, c2010, [cit. 10. 2. 2011], <http://www.kormany.hu/download/3/11/10000/Hungary\%20s\%20f lat\%20rate\%20personal\%20income\%20tax.pdf $>$.

[13] Saavedra, P. - Marcincin, A. - Valachy, J. (2007): Flat Income Tax Reforms. In Gray, C. W. - Lane, T. - Varoudakis, A.: Fiscal policy and Economic Growth. Lessons for Eastern Europe and Central Asia. Washington, D. C., World Bank, pp.253-280.

[14] Sabirianova, K. - Buttrick, S. - Duncan, D. (2009): Global Reform of Personal Income Taxation, 1981-2005: Evidence from 189 Countries. [on-line], Bonn, Institut zur Zukunft der Arbeit, Discussion Paper 4228, c2009, [cit. 10. 2. 2011], <http://ftp.iza.org/dp4228.pdf>.

[15] Vörös, G. - Kodenko, J. - Komáromi, K. (2010): Flat Rate Personal Income Tax. Public Finance Quarterly, 2010, vol. 55, no. 2, pp. 357374. 


\title{
Fiscal Consolidation and the New Flat Rate Individual Income Tax in Hungary
}

\author{
Mihály HŐGYE
}

\begin{abstract}
In the last two years the Hungarian people have witnessed several new measures in government's fiscal policy. To respond to global crisis that hit Hungary hard, the Bajnai government enacted a series of economic reforms and spending cuts in 2009. The Orban government elected in 2010 launched economic programs designed to promote growth by reducing administrative burdens on businesses and lowering the tax burdens on small businesses. The plan also includes strict control of budgetary expenditures, and a "crises-tax" on different sectors which would remain in effect for minimum 2 years. One of the most popular plans seems to be the launch of a "flat-rate" individual tax replacing the existing progressive tax aiming to increase supply of labor and so tax base, to improve tax compliance and the reduce cost of taxation. The paper analyses the recent changes from theoretical and practical views focusing on expected effects of the new flat rate individual income tax system. At first glance it seems to be that this new fiscal measure has just basically anti-consolidation effects on government budgetary position loosing significant revenues from income taxes. From international lessons it is expected that that there will be no Laffer-type behavioral responses generating revenue increases from the tax cut elements of the reform. The impact of the flat tax on work incentives might be expected only in short run. The flat rate reduces the flexibility of government to use tax rates as one of the "strong" weapons in budgetary policy when it becomes unavoidable. In many developed countries a wide range of tax expenditure is still applied in a more or less progressive personal income tax system. In a system where tax expenditures are widely used tax compliance may systematically improved if burdens and benefits are linked.
\end{abstract}

Key words: Fiscal policy; Tax principles; Tax system; Flat rate tax; Social policy.

JEL classification: $\mathrm{H} 2$. 